\title{
Early-life events associated with first-lactation performance in pasture-based dairy herds
}

\author{
G. M. Chuck, ${ }^{* 1}$ P. D. Mansell, $†$ M. A. Stevenson, $†$ and M. M. Izzo* \\ ${ }^{*}$ Apiam Animal Health, East Bendigo, Victoria 3550, Australia \\ †Faculty of Veterinary and Agricultural Sciences, The University of Melbourne, Parkville, Victoria 3010, Australia
}

\begin{abstract}
This was a prospective cohort study to determine how events from birth until first calving affect performance during the first lactation in pasture-based dairy herds in Victoria, Australia. Events during the preweaning (0-84 d), prepubertal (85-473 d), and postpubertal (474-804 d) periods were recorded in 6 herds, and their association with first-lactation 100-d and 250-d total milk, fat, and protein yields was quantified. Predictors of first-lactation performance included passive transfer status as a calf; season of birth; age of dam; the presence or absence of dystocia at the time of the heifer's birth; the presence or absence of preweaning diarrhea; preweaning, prepubertal, and postpubertal average daily weight gain; age at first calving; the presence or absence of periparturient disease at first calving; sex of the first-born calf; the presence or absence of a stillborn calf at the first calving; and requirement of assistance at the first calving. Lactation performance was quantified using cumulative 100-d and 250-d milk, fat, and protein yields estimated from herd recording. A multivariable linear regression model was developed for each outcome: cumulative 100-d milk, fat, and protein yield and cumulative 250 -d milk, fat, and protein yield. Heifers that experienced dystocia at the time of their birth produced $7.6 \mathrm{~kg}$ [95\% confidence interval (CI): 1.8-13.3] less fat and $4.8 \mathrm{~kg}$ (95\% CI: 0.6-8.9) less protein at $100 \mathrm{~d}$ in milk in the first lactation compared with heifers that were delivered without dystocia. Heifers born in the summer and autumn produced $20 \mathrm{~L}$ (95\% CI: 0.8-40) more milk and $20 \mathrm{~kg}$ (95\% CI: 5.9-33) more protein at $250 \mathrm{~d}$ in milk in the first lactation compared with heifers born in the spring. For $100 \mathrm{~g} / \mathrm{d}$ increases in prepubertal average daily gain, heifers produced an additional 182 L (95\% CI: 149-216) of milk, $4.1 \mathrm{~kg}$ (95\% CI: 2.8-5.5) of fat, and $4.0 \mathrm{~kg}$ (95\% CI 3.1-5.0) of protein at $100 \mathrm{~d}$ in milk and an additional $345 \mathrm{~L}$
\end{abstract}

Received January 22, 2017.

Accepted November 27, 2017.

${ }^{1}$ Corresponding author: gemmachuck@gmail.com
(95\% CI 264-425) of milk, $6.1 \mathrm{~kg}$ (95\% CI 3.2-9.0) of fat, and $7.5 \mathrm{~kg}$ (95\% CI 5.3-9.7) of protein at $250 \mathrm{~d}$ in milk. Postpubertal average daily gain was positively associated with 100-d milk yield and 250-d milk yield and protein production. We conclude that of all the growth periods assessed in this study, events that occurred during the prepubertal period (85-473 d of age) had the greatest effect on first-lactation performance.

Key words: lactation performance, growth, preweaning, prepubertal, postpubertal

\section{INTRODUCTION}

In dairy heifers, early-life events, including episodes of disease, dystocia at the time of birth, and colostrum feeding, have been associated with subsequent lactation performance (Britney et al., 1984; Heinrichs and Heinrichs, 2011; Mohd Nor et al., 2013). These events may exert their effect directly on lactation performance or indirectly through their effect on the risk of disease, age at first calving (AFC), BW at first calving, and $\mathrm{BCS}$ at first calving.

Milk yield, fat, and protein production have been shown to be affected by early calf health status (Svensson and Hultgren, 2008; Heinrichs and Heinrichs, 2011). Heinrichs and Heinrichs (2011) found that the presence of dystocia (defined as the provision of mechanical assistance to deliver a calf) was associated with a $569-\mathrm{kg}$ decrease in milk production and an 8.6-kg decrease in protein production over the first lactation compared with calves born without assistance. The number of days ill due to diarrhea or respiratory disease during the first 4 mo of life has been shown to have a negative association with 305-d mature equivalent and actual milk, fat, and protein production in the first lactation. Stanton et al. (2012) found that calves with respiratory disease at 2 to 4 mo of age had first test milk yields reduced by $1.1 \pm 0.6 \mathrm{~kg}$. These findings are not consistent with other studies that showed no effect of calfhood morbidity on subsequent milk production (Britney et al., 1984; Warnick et al., 1995).

The preweaning period is defined as the time from birth until milk feeding ceases. Numerous studies have 
shown that preweaning nutrition and ADG have a lasting effect on subsequent lactation performance (Shamay et al., 2005; Moallem et al., 2010; Soberon et al., 2010; Davis Rincker et al., 2011; Soberon and Van Amburgh, 2013). Hoffman and Funk (1992) suggested that the improved lactation performance was due to an increase in ADG and therefore increased BW at first calving.

The prepubertal period is defined as the first allometric phase of growth from 2 to 3 mo of age to the completion of several estrous cycles (Sinha and Tucker, 1969). The effect of high ADG in the prepubertal period on subsequent milk production has been widely researched with variable findings (Capuco et al., 1995; Sejrsen and Purup, 1997; Van Amburgh et al., 1998; Lammers et al., 1999; Macdonald et al., 2005; Zanton and Heinrichs, 2005; Soberon et al., 2012). High-level feeding on a corn silage diet led to excessive fat deposition and increased accumulation of adipocytes within the mammary parenchyma along with reduced mammary parenchymal DNA and RNA (Capuco et al., 1995). Growth rates greater than 600 to $700 \mathrm{~g} / \mathrm{d}$ during the prepubertal phase have been found to have a permanent negative effect on subsequent milk yield potential (Sejrsen and Purup, 1997). This negative effect is similar across dairy breeds, although the feeding level required to cause this negative effect can differ according to breed. Conversely, first-lactation milk yield has been found to be highest in heifers gaining 850 to $970 \mathrm{~g} / \mathrm{d}$ during the prepubertal period (Krpálková et al., 2014), with heifers achieving this ADG producing, on average, around $521 \mathrm{~kg}$ more milk over a $305-\mathrm{d}$ lactation compared with those with lower ADG. Fat and protein milk components were also significantly greater in the higher ADG group.

The postpubertal period can be defined as the period after the onset of detected estrus until structural maturity. Some studies have shown that there is no effect on lactation performance of ADG during this period (Abeni et al., 2000), whereas other studies have shown an association (Hoffman et al., 1996; Van Amburgh et al., 1998). The optimal ADG for all 3 growth periods is yet to be defined because of these inconsistencies in the literature. Most of these studies were carried out in non-seasonally calving herds fed either TMR or herds in which concentrate feeds and conserved forages accounted for most of the daily energy intake. To the best of our knowledge, the effect of early-life events on first-lactation performance has never been investigated in Australian pasture-based dairy heifers. To address this knowledge gap, the aim of this study was to determine which factors measured from birth until first calving are associated with first-lactation performance in 6 seasonally calving, pasture-based dairy herds in Victoria, Australia.

\section{MATERIALS AND METHODS}

This was a prospective cohort study of individual dairy heifers on 6 dairy herds in southwest Victoria. Data collection took place over a 5 -yr period. Selection of dairy herds was purposive and largely based on herd manager compliance with a demonstrated ability to record and maintain individual animal event details to a high level of detail. Two herds were selected with a herd size of less than 300 milking cows, 2 herds with 300 to 450 milking cows, and 2 herds with greater than 450 milking cows. One of the herds comprised $100 \%$ Holstein-Friesian cows, 1 herd comprised 100\% Jersey cows, and the remaining 4 herds had a combination of Holstein-Friesians, Jerseys, Aussie Reds, and their crosses. In all herds, cows were milked twice daily. During the calving season, calves were removed from the calving area(s) at least once daily.

Prior to the start of the first calving season of the study follow-up period, a comprehensive questionnaire on calf rearing practices was administered by the senior author to each participating herd manager. The questionnaire took 1 to $2 \mathrm{~h}$ to administer and solicited details on general herd information, precalving management, record management, colostrum management, feeding regimens, calf environment, health management, and weaning management.

\section{Data Recording}

All heifers were born outside in paddocks with their dams grouped according to estimated calving date. For every heifer calf born between February 2011 and November 2012, the following details were recorded on preprinted recording sheets at the time of birth: unique animal identification number, date of birth, breed of dam, age of dam, breed of calf, whether the calf was actively fed colostrum versus being left on the dam, whether the calf experienced dystocia at birth, whether she was one of a twin, and whether she experienced diarrhea during the preweaning period. The presence of diarrhea was defined as visibly loose feces of decreased consistency, with or without the presence of mucous or blood. Records of disease events were kept until weaning. Data were checked by the senior author at weekly herd visits to ensure that all records were complete.

Active feeding of first-milking colostrum by teat or esophageal feeder was encouraged as a routine management practice in all herds. After administration of colostrum, calves were fed between 10 and $20 \%$ of their BW in whole waste milk per feed $(4-8 \mathrm{~L} / \mathrm{d})$. Higher daily volumes were associated with twice daily feeding. Calf starter with a minimum of $18 \% \mathrm{CP}$ was available to all calves from birth, as was ad libitum fresh water. 
All calves were reared in group housing with between 5 and 15 calves per pen. Calves were housed for a minimum of 3 wk, after which calves from 3 of the herds had access to pasture with undercover shelter. The calves in the remaining 3 herds were housed until weaning. The mean age of weaning was $68 \mathrm{~d}$ (range: 49-84 d). After weaning, all heifers were managed in groups of 30 to 40 heifers at pasture. Supplementary feeding with concentrates and forage varied across herds and seasons.

\section{Measurement of Passive Transfer Status}

Passive transfer of immunoglobulins was indirectly assessed by measuring serum total solids (STS). Studies have shown that calf STS concentrations are highly correlated with immunoglobulin status (Naylor and Kronfeld, 1977). When interpreted at the group level, there is a good correlation between STS and serum IgG, as measured by the radial immunodiffusion assay. The radial immunodiffusion assay is deemed to be the gold standard in the determination of immunoglobulin level (Godden, 2008). A jugular venous sample was obtained from all apparently healthy heifer calves between $24 \mathrm{~h}$ and $7 \mathrm{~d}$ of age. Calves were categorized as healthy if no signs of clinical disease (e.g., inappetance, lethargy, diarrhea, or respiratory disease) had been observed by the herd manager for the period from birth to the time of STS sampling. Calves were not sampled if they were assessed by the investigator to be greater than $5 \%$ clinically dehydrated at the time of STS sampling, as dehydration would have falsely increased the STS. The disease status of all excluded calves was recorded. Blood samples were collected into plain tubes (BD Vacutainer rapid serum tube; Becton Dickinson, Franklin Lakes, NJ) and centrifuged for 3 min (800-1 Electric Centrifuge, $1,795 \times g$; Laboratory Medical Practice, China). Serum was then collected and STS was measured (g/ dL) using an optical temperature compensated clinical refractometer (model 9581306, Australian Scientific Pty Ltd., Kotara, NSW, Australia). The refractometer was calibrated every 10 samples using distilled water.

\section{Measurement of ADG}

Average daily gain was calculated for 3 time periods: (1) from birth to approximately 1 mo of age (ADG1); (2) from approximately 1 mo of age to first breeding, at approximately 14 mo of age (ADG2); and (3) from first breeding to just before first calving, at approximately 24 mo of age (ADG3).

ADG, Birth to Weaning. Calves were weighed using hanging weigh scales (model 205430, Shoof Australia, Tullamarine, VIC, Australia) with a cradle (model 210065, Shoof Australia), and the BW (kg) was recorded. The scales were regularly calibrated. Each calf was weighed once between $24 \mathrm{~h}$ and $7 \mathrm{~d}$ of age, and the weight was recorded (W1). The second weigh event occurred at a median age of $29 \mathrm{~d}$ (W2; range: $20-47 \mathrm{~d}$ ) using the same method. Average daily gain (g/d) was calculated as follows:

$$
\operatorname{ADG} 1(\mathrm{~g} / \mathrm{d})=\frac{\mathrm{W} 2-\mathrm{W} 1(\mathrm{~g})}{\text { difference }(\mathrm{d}) \text { between } \mathrm{W} 1 \text { and } \mathrm{W} 2}
$$

ADG, Weaning to First Breeding. Age at first breeding varied across herds due to variations in calving patterns and herd management. Within 2 wk of first breeding, all heifers were weighed (W3) using calibrated static scales (Tru-Test 5000 series, Tru Test Pty Ltd., Brisbane, QLD, Australia), which were transported to each herd in a mobile crush. The median age at first breeding was $415 \mathrm{~d}$ (range: 353-473 d). All herds used AI followed by a period of potential natural service. The average daily weight gain (ADG2; g/d) between the second weight in the preweaning period (W2) and the weight at first breeding (W3) was calculated.

ADG, First Breeding to Calving. All heifers were weighed by the senior author using calibrated static scales (Tru-Test 5000 series, Tru Test Pty Ltd.) in a mobile crush approximately 2 to 4 wk before expected first calving. An assessment of BCS on a scale of 1 to 8 (Earle, 1976) was made by the senior author for each heifer at the time of weighing. Average daily weight gain (ADG3; g/d) between the weight at first breeding (W3) and the weight at first calving (W4) was calculated.

\section{Measurement of First-Lactation Performance}

Lactation performance parameters, including cumulative 100-d lactation yield (L), fat $(\mathrm{kg})$, and protein $(\mathrm{kg})$ and cumulative 250-d lactation yield (L), fat $(\mathrm{kg})$, and protein $(\mathrm{kg})$, were calculated using monthly herd testing data from commercial herd testing centers. Milk fat and protein yield was measured using mid-infrared spectroscopy as part of each herd's routine milk supply arrangements. Heifers were sampled during morning and afternoon milking visits every month (for a maximum of 10 herd tests) until the end of their first lactation. Heifers with a lactation length of less than $100 \mathrm{~d}$ were excluded from the analysis. Data obtained for each heifer for each herd test included liters of milk, kilograms of fat, and kilograms of protein. Herd testing data were sent electronically in digital format (Excel, Microsoft Corp., Redmond, WA) from the herd test centers to the senior author. Milk yield and components 
Table 1. Independent variables associated with first-lactation performance

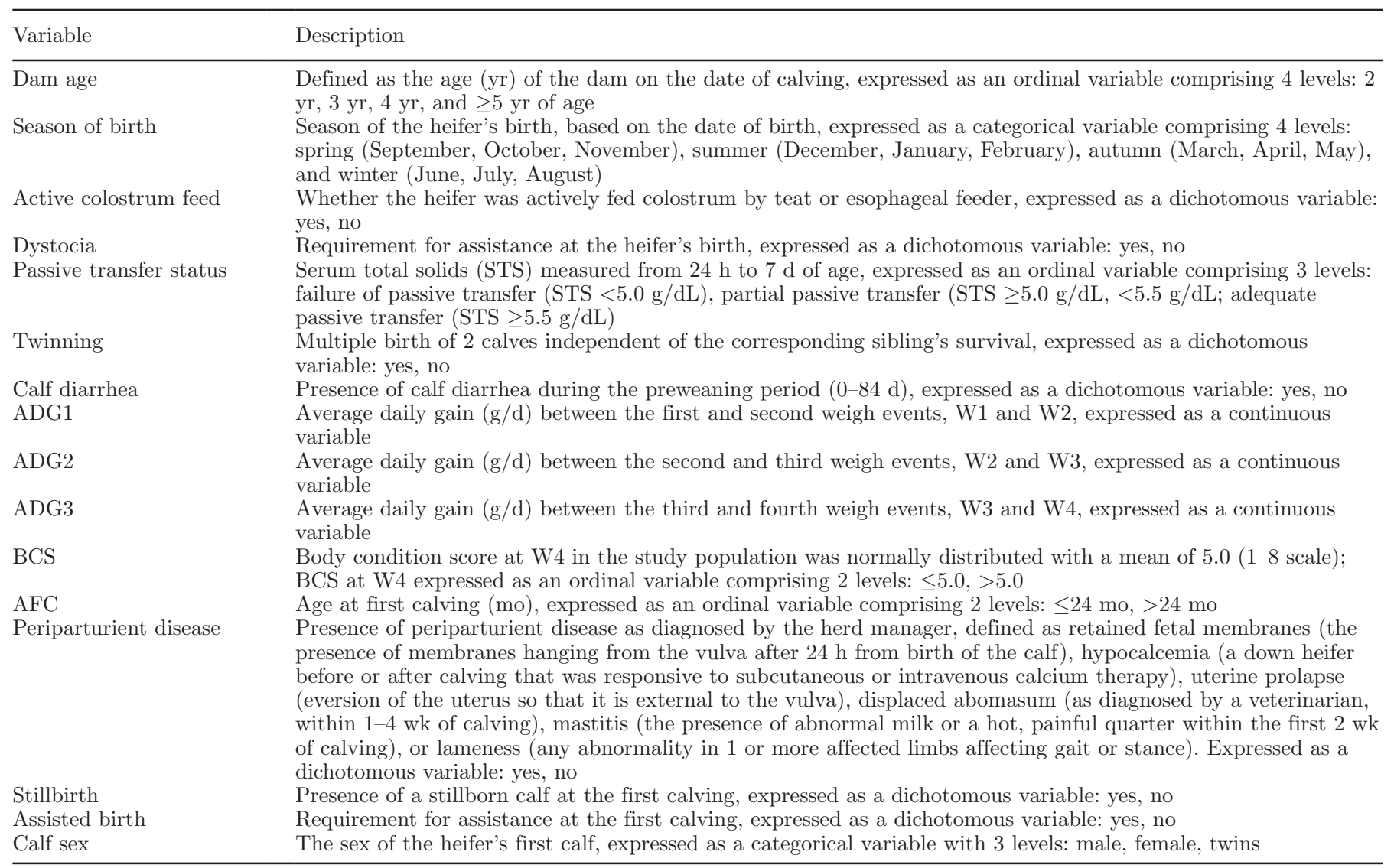

at $100 \mathrm{~d}$ and $250 \mathrm{~d}$ in lactation were estimated using an interpolation technique implemented in Dairy Data (Warrnambool Veterinary 2015, version 9.0; Warrnambool, Victoria, Australia). The criteria for calculation included the first herd test value being obtained within $60 \mathrm{~d}$ of calving, the maximum period between consecutive herd tests being $60 \mathrm{~d}$, and the minimum lactation length being 100 d. Animal ethics approval was granted from The University of Melbourne Animal Ethics Committee (approval number 1312898.1).

\section{Statistical Analyses}

For this study, we hypothesized that the independent variables shown in Table 1 were associated with firstlactation performance. All data were analyzed using Stata/IC version 13.0 for Windows (StataCorp LP, College Station, TX). Each of the explanatory variables listed above were selected in turn and included as a single explanatory variable in a linear regression model with the first outcome of interest, milk yield at $100 \mathrm{~d}$ of lactation. The significance of the association between each of the explanatory variables and 100-d milk yield was quantified using the $F$-statistic. Missing data were assigned a code and quantified for each explanatory variable in the univariable analysis. This approach was repeated using 100-d fat (kg), 100-d protein (kg), 250-d yield (L), 250-d fat (kg), and 250-d protein (kg).

A multivariable linear regression model was developed to quantify the association between each of the hypothesized explanatory variables and each outcome of interest, adjusting for the effect of known confounders. To reduce the number of explanatory variables used in the initial multivariable model, only variables with a $P$ value $<0.2$ from the univariable models were considered for inclusion in the multivariable model. Several of the explanatory variables that were significant in the univariable analysis $(P<0.2)$ had missing values within each category. Where the level of missing data was less than $5 \%$ or greater than or equal to $10 \%$ of the total number of observed values, these missing observations were dropped from the data set. If the level of missing data was greater than or equal to $5 \%$ but less than $10 \%$ of the observations for that variable, multiple imputation was used to impute these missing values using the mi impute procedure in Stata. The multivariable linear regression model was then developed using the data set comprising the imputed values. 
Collinearity between each of the candidate explanatory variables was tested for using the pwcorr procedure in Stata. Candidate explanatory variables that were not correlated with other candidate explanatory variables (Tabachnick and Fidell, 2001) were selected for inclusion in each of the multivariable models. Breed of the heifer and her dam were not included as explanatory variables in the multivariable models because collinearity existed between breed of the heifer, BW, and ADG. The effect of breed on production is well known, with Friesians having higher milk production than Jersey and cross-breed heifers. We found no evidence of collinearity between ADG periods, which meant that a calf with a high ADG in ADG1 was not more or less likely to have a higher rate of gain in a subsequent ADG period. Collinearity did exist between ADG period and BW. This was not surprising because a high ADG between 2 weigh events is likely to result in a high BW at the second weigh event. Given the exclusion of breed from the analyses and the strong association between breed and BW (with Friesians being heavier than Jerseys), it was concluded that ADG was a more meaningful explanatory variable for lactation performance because its value was not collinear with breed.

The multivariable models took the form

$$
Y_{i}=\beta_{0}+\beta_{1} x_{1 i}+\beta_{2} x_{2 i}+\ldots+\beta_{m} x_{m i}+\varepsilon_{i} .
$$

In Equation 2, $Y_{i}$ represents the outcome variable of interest for the $i$ th heifer, $\beta_{0}$ represents the intercept term, and $\beta_{1}, \ldots, \beta_{m}$ represents the regression coefficients for each of the $m$ explanatory variables, and $\varepsilon_{i}$ represents the model error term. A backward stepwise approach was used to select explanatory variables to be included in the final model. Explanatory variables that were not statistically significant were removed from the model one at a time, beginning with the least significant, until the estimated regression coefficients for all explanatory variables retained were significant at an $\alpha$ level of less than 0.05. Herd (a categorical variable comprising 6 levels) was included in each of the models as a fixed effect to account for the confounding effect of herd on each of the outcome variables. The effect of herd on each of the outcome variables was parameterized in the model as a fixed, rather than a random, effect because selection of herds for this study was purposive and not derived from a random sample of Victorian dairy herds (Snijders, 2005).

Biologically plausible 2-way interactions between explanatory variables in the final multivariable model were tested, and none were significant at the $\alpha$ level of 0.05. Frequency histograms were plotted for the Studentized residuals and a scatter plot constructed showing leverage as a function of normalized squared residuals from the multivariable model.

\section{RESULTS}

\section{0-d Performance Parameters}

Descriptive Analysis. The final data set for 100-d performance parameters comprised herd test records for 433 heifers. Counts of heifers stratified by herd and breed are shown in Table 2. Heifers that did not meet the criteria for calculation of lactation performance indicators ( $\mathrm{n}=124$ for $100 \mathrm{~d}$; $\mathrm{n}=179$ for $250 \mathrm{~d}$ ) were excluded from the data set. The mean average production at 100 DIM was $2,248 \mathrm{~L}, 86 \mathrm{~kg}$ of fat, and $70 \mathrm{~kg}$ of protein. The 100-d milk yields ranged from 1,033 to $3,901 \mathrm{~L}$, fat yields ranged from 39 to $138 \mathrm{~kg}$, and protein yields ranged from 30 to $124 \mathrm{~kg}$. Of the 433 heifers, there were $83(19 \%)$ with failure of passive transfer, 102 (24\%) with partial passive transfer, and 243 (56\%) with adequate passive transfer. There were 5 missing records for STS. The majority of heifers $(n=230,53 \%)$ were born in winter. Autumn was the next most common season of birth ( $\mathrm{n}=128,30 \%)$, followed by spring ( $\mathrm{n}$ $=40,9 \%)$. Only 35 heifers $(8 \%)$ were born in summer. There were 290 heifers with Friesian dams (66\%), 75 with Jersey dams (17\%), and 72 with cross-breed dams (16\%). Of the 433 heifers, $205(47 \%)$ were Friesian, 79 (18\%) were Jersey, and 152 (35\%) were cross-bred. There were 428 records for the age of the heifers' dam; 164 dams (38\%) were 2 yr old, 80 dams (18\%) were $3 \mathrm{yr}$ old, 47 dams (11\%) were 4 yr old, and 137 dams (32\%) were 5 yr old or greater. A total of 19 heifers $(4 \%)$ were left to suckle their dam and were therefore not actively fed colostrum. Of 433 heifers, 33 experienced dystocia at their time of birth (8\%), and the remaining 400 were born without any assistance. There were 13 heifers $(3 \%)$ born as one of twins. Preweaning diarrhea affected 22 heifers (5\%), and 411 heifers (95\%) did not experience diarrhea in the preweaning period. There were 180 heifers $(42 \%)$ that calved for the first time at less than or equal to 24 mo of age and 24 heifers $(6 \%)$ that gave birth to a stillborn calf. Of the 433 heifers, $31(7 \%)$ required assistance to deliver their calf and $47(11 \%)$ suffered some form of sickness around the time of their first calving. A total of 222 heifers $(51 \%)$ calved with a BCS of less than or equal to 5 using a 1-to-8 scale. Descriptive statistics for 100-d lactation performance are shown in Table 3.

Multivariable Analyses. The initial multivariable model included the following explanatory variables: age of dam, season of birth, active colostrum feeding, dystocia, passive transfer status, twinning, presence of calf diarrhea, ADG2, ADG3, BCS at W4, AFC, pres- 
Table 2. Counts of heifers with data available for the cumulative 100-d and 250-d lactation performance analyses, stratified by breed and herd

\begin{tabular}{|c|c|c|c|c|c|}
\hline Herd & $\mathrm{n}$ & Friesian & Jersey & Cross-breed & Missing \\
\hline \multicolumn{6}{|c|}{ 100-d analyses } \\
\hline 1 & 56 & 0 & 56 & 0 & 0 \\
\hline 2 & 43 & 37 & 3 & 2 & 1 \\
\hline 3 & 23 & 12 & 11 & 0 & 0 \\
\hline 4 & 201 & 58 & 0 & 143 & 0 \\
\hline 5 & 90 & 77 & 8 & 5 & 0 \\
\hline 6 & 20 & 20 & 0 & 0 & 0 \\
\hline Total & 433 & 204 & 78 & 150 & 1 \\
\hline \multicolumn{6}{|c|}{ 250-d analyses } \\
\hline 1 & 49 & 0 & 49 & 0 & 0 \\
\hline 2 & 41 & 36 & 2 & 2 & 1 \\
\hline 3 & 20 & 9 & 11 & 0 & 0 \\
\hline 4 & 184 & 53 & 0 & 131 & 0 \\
\hline 5 & 71 & 60 & 7 & 4 & 0 \\
\hline 6 & 0 & 0 & 0 & 0 & 0 \\
\hline Total & 365 & 158 & 69 & 137 & 1 \\
\hline
\end{tabular}

ence of periparturient disease, stillbirth at the first calving, assisted birth at the first calving, and calf sex at the first calving. Using our criteria for dealing with missing data, multiple imputation of missing values was not required. Only 0.8 and $2.5 \%$ of observations were missing from the explanatory variables of dam age and passive transfer status, respectively. Observations that were not recorded for ADG2, ADG3, AFC, BCS at first calving, periparturient disease, assisted birth, and stillbirth were not imputed because these observa- tions were greater than or equal to $10 \%$ of the total observations for their respective category. The observations were "missing" because these animals had exited the study before reaching those temporal data points, and multiple imputation of these data would have been inappropriate. Thus, the multivariable analysis was conducted on a data set in which there were no missing values in any of the candidate explanatory variables. The data used in the final multivariable models for milk, fat, and protein yields were derived from 324,

Table 3. Descriptive statistics of continuous explanatory variables and each of the 3 outcome variables for the cumulative 100-d and 250-d lactation performance multivariable models

\begin{tabular}{|c|c|c|c|c|c|}
\hline $\begin{array}{l}\text { Explanatory } \\
\text { variable }\end{array}$ & $\mathrm{n}$ & $\begin{array}{l}\text { Mean } \\
\text { (SD) }\end{array}$ & $\begin{array}{c}\text { Median } \\
(\mathrm{Q} 1, \mathrm{Q} 3)^{1}\end{array}$ & $\begin{array}{l}\text { Minimum, } \\
\text { maximum }\end{array}$ & $\begin{array}{c}\text { Missing } \\
\text { (no.) }\end{array}$ \\
\hline \multicolumn{6}{|l|}{ 100-d analyses } \\
\hline $\mathrm{ADG}^{2}(\mathrm{~g} / \mathrm{d})$ & 422 & $470(170)$ & $480(370,590)$ & $-170,920$ & 11 \\
\hline $\mathrm{ADG} 2^{3}(\mathrm{~g} / \mathrm{d})$ & 392 & $680(130)$ & $680(580,790)$ & 400,950 & 41 \\
\hline $\mathrm{ADG}^{4}(\mathrm{~g} / \mathrm{d})$ & 382 & $700(110)$ & $690(630,770)$ & $390,1,060$ & 51 \\
\hline $\mathrm{W} 3^{5}(\mathrm{~kg})$ & 400 & $312(56.4)$ & $311(266,354)$ & 188,448 & 33 \\
\hline $\mathrm{W} 4^{6}(\mathrm{~kg})$ & 407 & $494(69.7)$ & $497(447,542)$ & 329,666 & 26 \\
\hline Milk volume $(\mathrm{L})$ & 433 & $2,248(576)$ & $2,194(1,165,3,567)$ & $1,033,3,901$ & 0 \\
\hline Milk fat $(\mathrm{kg})$ & 433 & $86(20)$ & $86(44,128)$ & 39,138 & 0 \\
\hline Milk protein (kg) & 433 & $70(17)$ & $68(58,82)$ & 36,110 & 0 \\
\hline \multicolumn{6}{|l|}{ 250-d analyses } \\
\hline ADG1 (g/d) & 354 & $480(180)$ & $480(380,600)$ & $-170,920$ & 11 \\
\hline ADG2 (g/d) & 328 & $670(120)$ & $670(580,780)$ & 400,950 & 37 \\
\hline ADG3 (g/d) & 320 & $700(110)$ & $690(630,760)$ & $390,1,060$ & 45 \\
\hline W3 $(\mathrm{kg})$ & 336 & $309(55)$ & $304(264,351)$ & 188,448 & 29 \\
\hline W4 (kg) & 341 & $490(69)$ & $492(444,538)$ & 329,666 & 24 \\
\hline Milk volume (L) & 365 & $5,301(1,249)$ & $5,119(4,382,6,131)$ & $2,784,9,224$ & 0 \\
\hline Milk fat $(\mathrm{kg})$ & 365 & $213(43)$ & $211(182,242)$ & 96,321 & 0 \\
\hline Milk protein $(\mathrm{kg})$ & 365 & $176(39)$ & $170(149,200)$ & 86,293 & 0 \\
\hline
\end{tabular}

${ }^{1} \mathrm{Q}=$ quartile.

${ }^{2}$ Average daily gain between the first and second weigh events.

${ }^{3}$ Average daily gain between the second and third weigh events.

${ }^{4}$ Average daily gain between the third and fourth weigh events.

${ }^{5}$ Body weight at the third weigh event.

${ }^{6}$ Body weight at the fourth weigh event. 
Table 4. Multivariable linear regression models [coefficient (SE)] for factors associated with cumulative 100-d milk, fat, and protein production

\begin{tabular}{|c|c|c|c|c|c|c|c|c|c|}
\hline Variable & 100-d yield (L) & $t^{1}$ & $P$-value & 100-d fat (kg) & $t$ & $P$-value & $100-d$ protein $(\mathrm{kg})$ & $t$ & $P$-value \\
\hline 2 & Ref. $^{3}$ & - & - & - & - & - & - & - & - \\
\hline 4 & $-110.5(52.94)$ & -2.09 & 0.038 & - & - & - & - & - & - \\
\hline$\geq 5$ & $-30.58(40.80)$ & -0.75 & 0.454 & - & - & - & - & - & - \\
\hline \multicolumn{10}{|l|}{ Dystocia } \\
\hline $\mathrm{ADG}^{5}{ }^{5}(\times 100 \mathrm{~g} / \mathrm{d})$ & $43.76(15.96)$ & 2.74 & 0.006 & NS & - & - & NS & - & - \\
\hline \multicolumn{10}{|l|}{$\mathrm{AFC}^{6}$ (mo) } \\
\hline$\leq 24$ & Ref. & - & - & Ref. & - & - & Ref. & - & - \\
\hline$>24$ & $177.4(35.84)$ & 4.95 & 0.000 & $8.367(1.354)$ & 6.18 & 0.000 & $6.829(0.9730)$ & 7.02 & 0.000 \\
\hline \multicolumn{10}{|l|}{ Herd } \\
\hline 1 & Ref. & - & - & Ref. & - & - & Ref. & - & - \\
\hline
\end{tabular}

${ }^{1} t$-statistic.

${ }^{2}$ Not significant in the multivariate analysis.

${ }^{3}$ Referent.

${ }^{4}$ Average daily gain between the second and third weigh events (in $100 \mathrm{~g} / \mathrm{d}$ increments).

${ }^{5}$ Average daily gain between the third and fourth weigh events (in $100 \mathrm{~g} / \mathrm{d}$ increments).

${ }^{6}$ Age at first calving.

324, and 326 heifers, respectively. Examination of the residuals for each model identified 13 observations that were outliers; these heifers were removed from the data set.

Regression coefficients and their standard errors from the multivariable linear regression models for $\mathrm{cu}-$ mulative 100-d milk, fat, and protein yields are shown in Table 4. Heifers born with dystocia produced 7.6 $\mathrm{kg}(95 \%$ CI: $1.8-13.3)$ less fat and $4.8 \mathrm{~kg}$ (95\% CI: 0.6-8.9) less protein at $100 \mathrm{~d}$ in lactation compared with those born without dystocia. There was no association between the presence of dystocia and 100-d milk yield. The age of a heifer's dam was associated with 100-d milk production, with heifers born to 4-yrold dams producing $111 \mathrm{~L}$ (95\% CI: 6-215) less at 100 d compared with heifers born to 2-yr-old dams. The multivariable analysis of 100-d lactation performance measures showed that the AFC was associated with the 100-d yield, fat, and protein production. Heifers that calved at greater than 24 mo of age produced an additional 177 L (95\% CI: 107-248) of milk, $8.4 \mathrm{~kg}$ (95\% CI: 5.7-11) of fat, and $6.8 \mathrm{~kg}$ (95\% CI: 4.9-8.7) of protein compared with heifers that calved at less than or equal to 24 mo of age. The ADG between the second and third weigh events (ADG2) was associated with all 3 measures of 100-d lactation performance. An additional $100 \mathrm{~g} / \mathrm{d}$ growth during this period was associated with an increase of 182 L (95\% CI: 149-216) of milk, $4.1 \mathrm{~kg}$
(95\% CI: $2.8-5.5)$ of fat, and $4.0 \mathrm{~kg}$ (95\% CI: 3.1-5.0) of protein at 100 DIM. A similar association was found between the ADG between the third and fourth weigh events (ADG3) and 100-d milk yield. For $100 \mathrm{~g} / \mathrm{d}$ increases in ADG, there was an additional $44 \mathrm{~L}$ (95\% CI: 12-75) of milk at 100 DIM. There was no association between ADG3 and 100-d fat or protein production.

\section{0-d Performance Parameters}

Descriptive Analyses. The final data set for 250-d performance parameters comprised 365 heifers. Counts of heifers stratified by herd and breed are shown in Table 2. The mean average production at $250 \mathrm{~d}$ in lactation was $5,300 \mathrm{~L}, 213 \mathrm{~kg}$ of fat, and $176 \mathrm{~kg}$ of protein. Milk yield ranged from 2,784 to 9,224 L, fat ranged from 96 to $321 \mathrm{~kg}$, and protein ranged from 86 to $293 \mathrm{~kg}$. Of the 365 heifers, there were 61 (17\%) with failure of passive transfer, $86(24 \%)$ with partial passive transfer, and 214 (59\%) with adequate passive transfer. There were 4 missing records for STS. Winter was the most common month of birth, with 200 heifers $(55 \%)$ born in this season. This was followed by autumn, in which122 heifers (34\%) were born. A total of $31(8 \%)$ and $12(3 \%)$ heifers were born in spring and summer, respectively. The age of a heifer's dam was recorded; 147 dams (40\%) were 2 yr old, 67 dams (18\%) were 3 yr old, 42 dams (12\%) were 4 yr old, and 106 dams (29\%) 
Table 5. Multivariable linear regression models [coefficient (SE)] for factors associated with cumulative 250-d milk, protein, and fat production

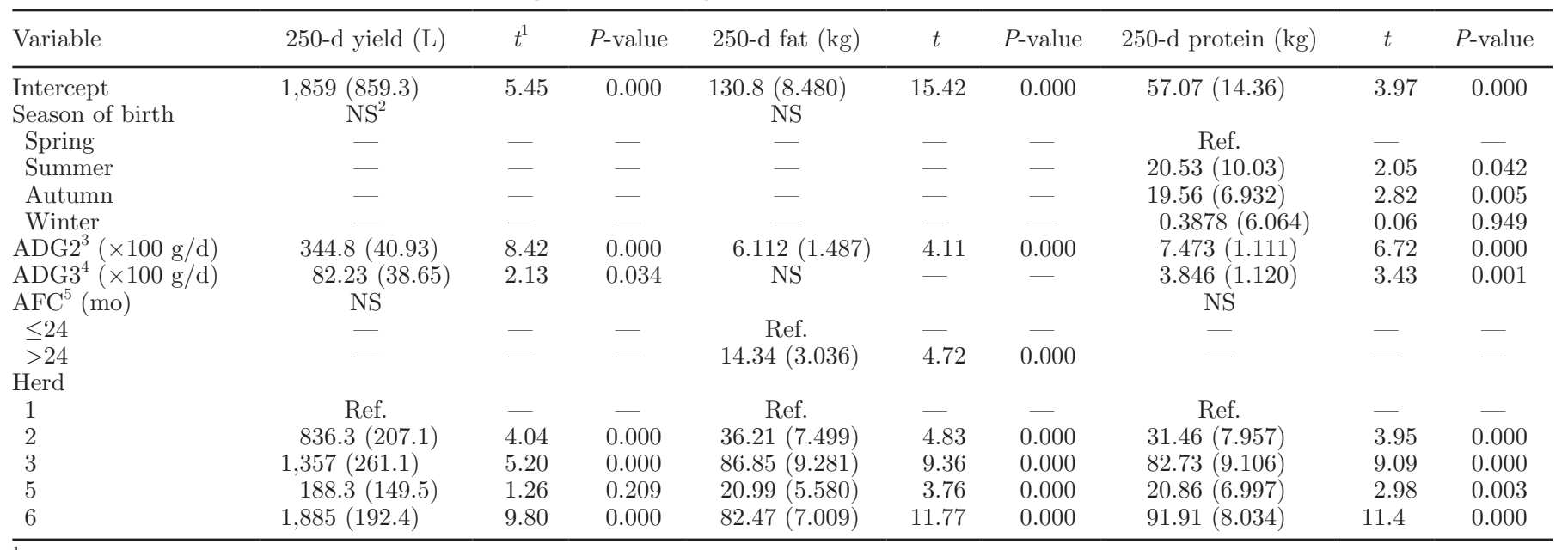

${ }^{1} t$-statistic.

${ }^{2}$ Not significant in the multivariate analysis.

${ }^{3}$ Average daily gain between the second and third weigh events (in $100 \mathrm{~g} / \mathrm{d}$ increments).

${ }^{4}$ Average daily gain between the third and fourth weigh events (in $100 \mathrm{~g} / \mathrm{d}$ increments).

${ }^{5}$ Age at first calving.

were 5 yr old or greater. One heifer was left to suckle her dam and was therefore not actively fed colostrum. Of 365 heifers, 28 experienced dystocia at their time of birth $(8 \%)$, and the remaining 337 were born without any assistance. There were 6 heifers $(2 \%)$ born as one of a pair of twins and 12 heifers (3\%) that suffered preweaning diarrhea. There were 154 heifers $(42 \%)$ that calved for the first time at less than or equal to 24 mo of age and 22 heifers $(6 \%)$ that gave birth to a stillborn calf. Of the 365 heifers, 27 (7\%) required assistance to deliver their calf, 42 (12\%) suffered some form of illness around the time of their first calving, and 203 (56\%) calved with a BCS of less than or equal to 5 using a 1-to-8 scale. Descriptive statistics for 250-d lactation performance are shown in Table 3.

Multivariable Analyses. The data sets in the final multivariable models for cumulative 250 -d milk, protein yield, and fat yield were derived from 285, 282, and 284 heifers, respectively (Table 5). Examination of the residuals from the multivariable models identified 14 , 15 , and 17 observations from the 250-d milk, fat, and protein data, respectively, that did not fit the rest of the data. These heifers were removed from the data set. Heifers born in summer and autumn produced $20(95 \%$ CI: $0.8-40)$ and $20 \mathrm{~kg}$ (95\% CI: 5.9-33) more protein than heifers born in spring. There was no association between being born in winter and 250 -d protein production. Heifers that were greater than 24 mo of age at the time of first calving produced $14 \mathrm{~kg}$ (95\% CI: 8.4-20) more fat than heifers that calved at less than or equal to 24 mo of age. There was no association between AFC and $250-\mathrm{d}$ milk or protein production.
The multivariable analysis showed that ADG2 was associated with 250-d milk, fat, and protein yield. For every $100 \mathrm{~g} / \mathrm{d}$ increase in ADG during this period, there was an additional 345 L (95\% CI: 264-425) of milk, $6.1 \mathrm{~kg}$ (95\% CI: $3.2-9.0)$ of fat, and $7.5 \mathrm{~kg}(95 \%$ CI: 5.3-9.7) of protein. A similar association was found with ADG3 and 250-d milk and protein production. An increase of $100 \mathrm{~g} / \mathrm{d}$ gain during this period was associated with an additional $82 \mathrm{~L}$ (95\% CI 6-158) of milk and $3.8 \mathrm{~kg}$ (95\% CI 1.6-6.1) of protein. There was no association between ADG3 and 250-d fat production. The season in which a heifer was born was associated with her protein production at $250 \mathrm{~d}$.

\section{DISCUSSION}

This study identified several early-life events associated with 100-d and 250-d lactation performance parameters in primiparous Victorian dairy heifers. Although not all the recorded events were associated with each of the performance parameters that were measured, these findings provide information on how events preceding first calving can affect first-lactation performance. For example, the occurrence of dystocia at birth had a significant negative association with 100-d fat and protein production, occurring approximately 27 mo after the dystocia event. These results support those of Heinrichs and Heinrichs (2011), who found that dystocia negatively affected milk production and protein yield for the 305-d mature equivalent and total lactation production in the first lactation. Neither milk yield at $100 \mathrm{~d}$ or $250 \mathrm{~d}$ were associated with dystocia in this study. The 
relationship between dystocia and subsequent lactation performance is not well understood but may be related to the sequelae of dystocia such as transient hypoxia, calf viability, and growth (Mee, 2008). The 100-d performance indicators were used not only to reflect peak milk production during the first lactation but also to indicate how well heifers have grown, developed, and transitioned into the milking herd. In this study, 250$\mathrm{d}$ performance parameters were used to reflect total lactation production of heifers. Many studies have used the 305-d milk and 305-d mature equivalent milk production indices to reflect overall lactation performance (Shamay et al., 2005; Heinrichs and Heinrichs, 2011), but in this study only a small proportion of primiparous heifers had lactations that extended to $305 \mathrm{~d}$. The shorter lactation lengths in this study may be explained by individual herd management decisions to dry cows off in response to pasture feed availability, pregnancy status, health, and production.

Age at first calving was associated with cumulative 100-d milk, fat, and protein production and cumulative 250-d fat production. Age at first calving that was greater than or equal to 24 mo of age had a positive association with early-lactation performance, which was evident only in later lactation in terms of fat yield. The results from previous studies are contradictory (Pirlo et al., 2000; Ettema and Santos, 2004; Nilforooshan and Edriss, 2004), which may be due to the different cutpoints used for the AFC and the different measures of performance used. Pirlo et al. (2000) and Ettema and Santos (2004) showed that delaying the AFC had a positive effect on first-lactation performance. In contrast, Nilforooshan and Edriss (2004) found that increasing the AFC above 24 mo of age had a negative effect on milk production. The findings from this study support those of Krpálková et al. (2014), who found that heifers calving for the first time at greater than or equal to 751 d (25 mo) had higher 100-d milk and fat yields compared with heifers calving at $23 \mathrm{mo}$ or less. Although it is acknowledged that cattle continue to grow beyond 24 mo of age, a cut-point of 24 mo was used in the present study due to mean average AFC being $24.3 \mathrm{mo}$, and 24 mo was the optimal AFC observed by Ettema and Santos (2004). The relationship between increased AFC and increased cumulative 100-d lactation performance may be attributed to a more skeletally mature animal with age. If younger heifers were indeed less skeletally mature with a lower BW at first calving, it is possible that they could not consume sufficient nutrients to achieve their genetic potential. Additionally, partitioning of nutrients toward growth could have occurred in younger, smaller heifers (Ettema and Santos, 2004). These 2 confounders may have resulted in poorer lactation performance in heifers calving at less than or equal to 24 mo of age. Younger, smaller heifers are more likely to have experienced dystocia and consequently experience health problems that can effect lactation performance (Erb et al., 1985). Finally, they are also less likely to cope with hierarchy pressures within the milking herd and compete for feed less successfully, which translates to reduced milk production and performance (Grant and Albright, 1995). Although ADG varied by breed, we elected not to include breed of the heifer in our multivariable analyses because breed was highly correlated with herd. Inclusion of herd in each model as a fixed effect accounted for unmeasured, herd-level characteristics in addition to the effect of heifer breed.

Average daily gain between the second and third weigh events (ADG2) was associated with both 100-d and 250-d performance outcomes. The second weigh event occurred at a median age of $29 \mathrm{~d}$ (range: 20-47 d), which is still during a heifer's first isometric phase of growth. The third weigh event occurred at approximately 14 mo of age (mean: $415 \mathrm{~d}$; range: 353-473 d), which is in the second isometric growth phase. Thus, the period between these 2 weigh events spans, but is not exclusive to, the allometric growth phase, which has traditionally been described as occurring from approximately 3 mo of age to just before onset of puberty (Sinha and Tucker, 1969; Swanson and Poffenbarger, 1979). During this allometric growth phase it has been shown that the mammary gland grows at a considerably faster rate than the body surface area. However, more recent studies have demonstrated that the mammary gland can shift to an allometric phase of growth immediately after birth if calves are fed an enhanced diet with increased nutrient intake above maintenance during the preweaning period (Meyer et al., 2006; Geiger et al., 2016; Soberon and Van Amburgh, 2017). A weigh event at weaning would have been ideal to give a more accurate estimation of ADG during the absolute prepubertal growth phase, but this was not possible given the resources available for this study. The calculated ADG takes into account the small differences in age between heifers at the weigh events and can still be considered an indicator of prepubertal or allometric growth. Milk, fat, and protein production during early (100 DIM) and later (250 DIM) lactation was associated with ADG during this predominantly allometric period. For every additional $100 \mathrm{~g}$ of BW gained per day, there was an increase of $182 \mathrm{~L}, 4.0 \mathrm{~kg}$ of protein, and $4.1 \mathrm{~kg}$ of fat at $100 \mathrm{~d}$ into lactation. Similarly, an additional $100 \mathrm{~g}$ of $\mathrm{BW}$ gained per day resulted in an increase of $345 \mathrm{~L}, 7.5 \mathrm{~kg}$ of fat, and $6.1 \mathrm{~kg}$ of protein at $250 \mathrm{~d}$ into lactation. These results show that a heifer grown at $800 \mathrm{~g} / \mathrm{d}$ during this period can be expected to produce an additional 1,034 L (95\% CI: 794-1,275) of milk, $18.3 \mathrm{~kg}$ (95\% CI: 9.6-27.1) of fat, and $22.4 \mathrm{~kg}$ 
(95\% CI: $15.9-29.0$ ) of protein during the first $250 \mathrm{~d}$ of lactation compared with a heifer grown at $500 \mathrm{~g} / \mathrm{d}$ during ADG2. Although the growth period differs slightly, these results support the findings of other studies in that prepubertal ADG significantly contributes to firstlactation performance (Capuco et al., 1995; Sejrsen and Purup, 1997; Van Amburgh et al., 1998).

In this study, the effect of a higher ADG was positive, resulting in increased milk and component production. However, a negative relationship has also been demonstrated at higher ADG than that achieved in this study (Sejrsen and Purup, 1997; Lammers et al., 1999). Zanton and Heinrichs (2005) suggested that the relationship between ADG and production is quadratic, with an "optimal" ADG being around $800 \mathrm{~g} / \mathrm{d}$. Sejrsen et al. (2000) stated that this optimal ADG will actually be variable depending on the genetic capacity of the cow to produce milk. Thus, the optimal daily gain will increase as the genetic capacity for milk yield increases. This is irrespective of feeding level (Sejrsen et al., 2000). Further investigation is required to determine a suitable benchmark for pasture-raised dairy heifers under Australian conditions.

The ADG between the third and fourth weigh events (ADG3) was associated with 100-d milk yield and 250$\mathrm{d}$ milk and protein production. In all of the analyses presented in this study, the magnitude of this association was much less than for ADG2. For example, a heifer grown at $800 \mathrm{~g} / \mathrm{d}$ during this postbreeding period produced an additional 247 L (95\% CI: 19-474) of milk and $8.5 \mathrm{~kg}$ (95\% CI: 2.0-15.1) of protein during the first $250 \mathrm{~d}$ of lactation compared with the situation where ADG3 was $500 \mathrm{~g} / \mathrm{d}$. Previous research supports these findings (Krpálková et al., 2014), although there are reports of both a positive and a negative effect of higher ADG during the postpubertal period on milk production (Hoffman et al., 1996; Abeni et al., 2000). These conflicting results are likely to be due to different study designs and the levels of nutrition provided to achieve different ADG. Some studies considered a high ADG to be $680 \mathrm{~g} / \mathrm{d}$ for Holsteins (Macdonald et al., 2005), whereas others considered an ADG of $940 \mathrm{~g} / \mathrm{d}$ to be high and $680 \mathrm{~g} / \mathrm{d}$ to be low (Van Amburgh et al., 1998). In terms of mammary development, this period of growth is defined as the second isometric growth phase where the rate of growth of the mammary gland has slowed and is comparable with the rate of growth of the body surface area (Sinha and Tucker, 1969). This may explain why the association between ADG3 and lactation performance is smaller than that between ADG2 and lactation performance. Average daily gain in all growth periods was analyzed as a continuous variable in a linear regression model for each outcome. However, the likelihood is that the relationship between
ADG and lactation performance measures is not infinitely linear. From previous research investigating the effects of high ADG on milk production (Zanton and Heinrichs, 2005), the likelihood is that an ADG point would be reached where lactation performance becomes adversely affected. This quadratic relationship was not observed in the present study because high ADG, exceeding $1,000 \mathrm{~g} / \mathrm{d}$, were not observed. A possible explanation for the adverse effect of high ADG on lactation performance, particularly during the prepubertal period, is the increased volume of adipocytes at the expense of mammary glandular cells in the mammary parenchyma (Capuco et al., 1995).

Heifers born in summer and autumn produced more protein at $250 \mathrm{~d}$ into lactation compared with heifers born in spring. With an average AFC of 24.1 mo, heifers born in summer and autumn were also likely to calve for the first time in summer and autumn, respectively. The variation in 250-d protein yields between summer-, autumn-, and spring-born heifers may be due to seasonal differences in climate, which in turn influences pasture growth rates, availability, and quality (Stevenson et al., 2003). Photoperiod and feeding behavior also varies by season and can influence lactation performance (Collier et al., 2006; Gorgulu et al., 2012).

The age of a heifer's dam was significant in the final multivariable model for 100-d milk production. Heifers born to 4-yr-old dams had a lower 100-d milk yield compared with heifers born to 2-yr-old dams. GonzálezRecio et al. (2012) observed the transgenerational negative effects on milk performance as the lactation number of the pregnant dam increases. This may be due to the higher yield produced in later lactations, the accumulation of unfavorable genetic mutations, or an increased number of epigenetic marks that are transmitted to the embryo in older dams (González-Recio et al., 2012). Alternatively, the significance of dam age on 100-d milk production in this study could relate to the relatively low numbers of heifers born to 4-yr-old dams in the 100-d analyses $(\mathrm{n}=47)$. Despite passive transfer status being significant in both the 100-d and 250-d performance univariable analyses, this variable was not included in any of the final multivariable models. This may be explained by the method and selection criteria for measuring passive transfer in the present study. There is good correlation between the TS (protein) level and immunoglobulin in the serum (Godden, 2008), and assessment of passive transfer status using this method is accurate and reliable (Naylor and Kronfeld, 1977). However, calves showing signs of clinical disease were not sampled, as any level of dehydration would falsely increase the STS and would not provide a true reflection of immunoglobulin transfer. Thus, calves with possible failure of passive transfer could not be 
assessed on lactation performance if they were displaying signs of clinical disease at the time of sampling. In addition, some calves with failure of passive transfer would have exited the study before first calving, and their lactation performance could not be measured. For example, in the 100-d milk yield final multivariable data set, there were complete observations for 324 animals. Of these, only 59 calves (18\%) had failure of passive transfer, 68 calves $(21 \%)$ had partial passive transfer, and 197 calves (61\%) had adequate passive transfer. In comparison, in the original data set, which included missing observations for some of the explanatory variables, there were 155 calves (20\%) with failure of passive transfer. The indirect benefits of adequate passive transfer of immunity on growth and morbidity are widely published (McEwan et al., 1970; Nocek et al., 1984; Robison et al., 1988; Donovan et al., 1998), but there is also evidence of direct effects of passive transfer on subsequent lactation performance (DeNise et al., 1989). Soberon and Van Amburgh (2011) described how calves fed high levels of colostrum followed by a high plane of milk nutrition resulted in improved feed conversion efficiency in the postweaning period compared with calves fed lower volumes of colostrum followed a high plane of milk nutrition. This indicates that it was the level of colostrum feeding that accounted for the variation in feed conversion efficiency (Soberon and Van Amburgh, 2011). It is unclear whether these effects are attributable to passive transfer of immunoglobulins or due to other bioactive factors present in colostrum, such as growth factors and hormones. In this study there was no effect of active colostrum feeding on lactation performance, although only 19 heifers in the final 100-d analyses and 1 heifer in the final 250-d analyses were not actively fed. Further research is required to determine the effect of colostrum supplementation on subsequent lactation performance.

The incidence of preweaning diarrhea had no obvious effect on any of the production measures. Some studies have suggested that preweaning disease events, such as diarrhea or respiratory disease, has a negative effect on lactation performance (Svensson and Hultgren, 2008; Heinrichs and Heinrichs, 2011; Stanton et al., 2012). Other studies have shown this not to be the case and that there is no lasting effect of calfhood morbidity on production (Britney et al., 1984; Warnick et al., 1995). The variation in results could be due to differences in study populations and definitions of clinical disease. In this study, there were production data for only 22 of the heifers that experienced preweaning diarrhea. The definition of preweaning diarrhea was when a calf had visibly loose feces either observed directly or on the tail or hind limbs. There was no score for the severity of the diarrhea or demeanor of the calf. Preweaning morbidity is difficult to quantify in a study such as this due to the variation in observational skills of the primary calf caretaker (Svensson et al., 2003). Although considerable care was taken to provide all participant herd managers with disease case definitions at the start of the study, research personnel were not present in all calf sheds all of the time. For this reason, we elected to use a simplified definition for preweaning morbidity: whether a calf was treated with antimicrobials or electrolytes during the preweaning period. However, many calves were treated metaphylactically by individual herd managers, and for this reason preweaning morbidity was not included as an explanatory variable in the analysis of the production data.

Previous studies have shown that a higher preweaning ADG has a positive effect on milk production later in life (Moallem et al., 2010; Soberon et al., 2010; Soberon and Van Amburgh, 2013). Some research suggests that preweaning growth can account for $25 \%$ variation in first-lactation milk production, which is greater than any genetic component (Soberon et al., 2010). This may be due to a greater mass of mammary parenchyma in heifers fed on a higher plane of nutrition during the preweaning period (Geiger et al., 2016). In this study, the ADG between the first and second weigh events did not significantly affect any of the 100-d or 250 -d production outcomes. The mean age at the first weigh event was $4 \mathrm{~d}$ and at the second weigh event was $28 \mathrm{~d}$. This does not include the entire preweaning period, and it would have been ideal to measure the BW of heifers at weaning. Weight gain during the first 4 wk of life was highly variable between herds and between calves in each herd. This may be due to breed differences, nutrition, morbidity events, and season of birth. Further collection and analysis of weight data during the preweaning period are required to observe whether there is any significance of preweaning ADG on lactation performance under temperate Australian conditions.

Body condition score at calving was not included in the final multivariable models, although it was highly significant in the 100-d and 250-d univariable analyses. This is in contrast to work done by Markusfeld et al. (1997), who demonstrated that the effects of BCS at calving were evident up to $180 \mathrm{~d}$ into the first lactation. In the present study, the researcher was the sole person responsible for the visual BCS of heifers, using a 1-to8 scale (InCalf, 2003). A cut-point of 5.0 was derived from the mean BCS being 5.1 (SD: 0.35), with a range of 4.0 to 6.0. There is a possibility that the effect of BCS at calving may have a significant effect on lactation performance if a lower cut-point had been used.

Heifers requiring assistance at their first calving did not perform any differently in terms of lactation perfor- 
mance compared with heifers that did not require assistance. One study showed that dystocia at first calving had a negative effect on 30-d yield but no effect later in lactation (Thompson et al., 1983). Considering that the performance parameters used in this study were at 100 $\mathrm{d}$ and $250 \mathrm{~d}$ into lactation, this effect was not observed, nor can it be compared. Furthermore, the definition of assisted birth was "any heifer that was assisted by the herd manager or a vet whether deemed necessary or not." There was no indication of the severity of the dystocia, and it is highly likely that intervention occurred in some instances where true dystocia (i.e., malposture or fetal oversize) was not present. This is a limitation of on-farm recording and field research involving multiple herds. The incidence of stillborn calves and periparturient disease, such as retained fetal membranes and metritis, was low, which may have contributed to the lack of effect that these variables showed on lactation performance.

\section{CONCLUSIONS}

Average daily gain during the prepubertal period had the largest influence on cumulative 100-d and 250-d lactation performance outcomes. Average daily gain during the postpubertal period was also associated with some lactation performance measures, but the strength of this association was much less. Improved nutrition and feeding of heifers during the prepubertal period to enable a higher ADG is likely to have a significant positive effect on milk, fat, and protein production during the first lactation. Events early in life such as dystocia and season of birth appear to have lasting effects on first-lactation performance. Measures to reduce the risk of dystocia, such as selection of calving-ease sires, are likely to improve subsequent lactation performance in Australian dairy herds.

\section{ACKNOWLEDGMENTS}

The authors acknowledge the participating herds in this study along with The Vet Group (Timboon, Australia), Dairy Australia (Southbank, Australia), and National Herd Development (Timboon, Australia) for their contributions.

\section{REFERENCES}

Abeni, F., L. Calamari, L. Stefanini, and G. Pirlo. 2000. Effects of daily gain in pre- and postpubertal replacement dairy heifers on body condition score, body size, metabolic profile, and future milk production. J. Dairy Sci. 83:1468-1478.

Britney, J. B., S. W. Martin, J. B. Stone, and R. A. Curtis. 1984. Analysis of early calfhood health-status and subsequent dairy-herd survivorship and productivity. Prev. Vet. Med. 3:45-52.
Capuco, A. V., J. J. Smith, D. R. Waldo, and C. E. Rexroad. 1995. Influence of prepubertal dietary regimen on mammary growth of Holstein heifers. J. Dairy Sci. 78:2709-2725.

Collier, R. J., G. E. Dahl, and M. J. VanBaale. 2006. Major advances associated with environmental effects on dairy cattle. J. Dairy Sci. 89:1244-1253.

Davis Rincker, L. E., M. J. Vandehaar, C. A. Wolf, J. S. Liesman, L. T. Chapin, and M. S. Weber Nielsen. 2011. Effect of intensified feeding of heifer calves on growth, pubertal age, calving age, milk yield, and economics. J. Dairy Sci. 94:3554-3567.

DeNise, S. K., J. D. Robison, G. H. Stott, and D. V. Armstrong. 1989. Effects of passive-immunity on subsequent production in dairy heifers. J. Dairy Sci. 72:552-554.

Donovan, G. A., I. R. Dohoo, D. M. Montgomery, and F. L. Bennett. 1998. Calf and disease factors affecting growth in female Holstein calves in Florida, USA. Prev. Vet. Med. 33:1-10.

Earle, D. 1976. A guide to scoring dairy cow condition. J. Agric. Victoria $74: 228-231$.

Erb, H. N., R. D. Smith, P. A. Oltenacu, C. L. Guard, R. B. Hillman, P. A. Powers, M. C. Smith, and M. E. White. 1985. Path model of reproductive disorders and performance, milk fever, mastitis, milkyield, and culling in Holstein cows. J. Dairy Sci. 68:3337-3349.

Ettema, J. F., and J. E. P. Santos. 2004. Impact of age at calving on lactation, reproduction, health, and income in first-parity Holsteins on commercial farms. J. Dairy Sci. 87:2730-2742.

Geiger, A. J., C. L. M. Parsons, and R. M. Akers. 2016. Feeding a higher plane of nutrition and providing exogenous estrogen increases mammary gland development in Holstein heifer calves. J. Dairy Sci. 99:7642-7653.

Godden, S. 2008. Colostrum management for dairy calves. Vet. Clin. Food Anim. 24:19-39. https://doi.org/10.1016/j.cvfa.2007.10.005.

González-Recio, O., E. Ugarte, and A. Bach. 2012. Trans-generational effect of maternal lactation during pregnancy: A Holstein cow model. PLoS One 7:e51816.

Gorgulu, M., M. A. Akyol, M. Boga, and S. Goncu. 2012. The effects of choice feeding and season on the feeding behaviour and growth performance of calves. J. Anim. Feed Sci. 21:263-275.

Grant, R. J., and J. L. Albright. 1995. Feeding behavior and management factors during the transition period in dairy cattle. J. Anim. Sci. 73:2791-2803.

Heinrichs, A. J., and B. S. Heinrichs. 2011. A prospective study of calf factors affecting first-lactation and lifetime milk production and age of cows when removed from the herd. J. Dairy Sci. 94:336-341.

Hoffman, P. C., N. M. Brehm, S. G. Price, and A. Prill-Adams. 1996. Effect of accelerated postpubertal growth and early calving on lactation performance of primiparous Holstein heifers. J. Dairy Sci. 79:2024-2031.

Hoffman, P. C., and D. A. Funk. 1992. Applied dynamics of dairy replacement growth and management. J. Dairy Sci. 75:2504-2516.

InCalf. 2003. The InCalf Book for Dairy Farmers. Dairy Australia, Southbank, Victoria, Australia.

Krpálková, L., V. E. Cabrera, M. Vacek, M. Stipkova, L. Stadnik, and P. Crump. 2014. Effect of prepubertal and postpubertal growth and age at first calving on production and reproduction traits during the first 3 lactations in Holstein dairy cattle. J. Dairy Sci. 97:3017-3027.

Lammers, B. P., A. J. Heinrichs, and R. S. Kensinger. 1999. The effects of accelerated growth rates and estrogen implants in prepubertal Holstein heifers on estimates of mammary development and subsequent reproduction and milk production. J. Dairy Sci. 82:1753-1764.

Macdonald, K. A., J. W. Penno, A. M. Bryant, and J. R. Roche. 2005. Effect of feeding level pre- and post-puberty and body weight at first calving on growth, milk production, and fertility in grazing dairy cows. J. Dairy Sci. 88:3363-3375.

Markusfeld, O., N. Galon, and E. Ezra. 1997. Body condition score, health, yield and fertility in dairy cows. Vet. Rec. 141:67-72.

McEwan, A. D., E. W. Fisher, and I. E. Selman. 1970. Observations on the immune globulin levels of neonatal calves and their relationship to disease. J. Comp. Pathol. 80:259-265. 
Mee, J. F. 2008. Prevalence and risk factors for dystocia in dairy cattle: A review. Vet. J. 176:93-101.

Meyer, M. J., A. V. Capuco, D. A. Ross, L. M. Lintault, and M. E. Van Amburgh. 2006. Developmental and nutritional regulation of the prepubertal heifer mammary gland: I. Parenchyma and fat pad mass and composition. J. Dairy Sci. 89:4289-4297.

Moallem, U., D. Werner, H. Lehrer, M. Zachut, L. Livshitz, S. Yakoby, and A. Shamay. 2010. Long-term effects of ad libitum whole milk prior to weaning and prepubertal protein supplementation on skeletal growth rate and first-lactation milk production. J. Dairy Sci. 93:2639-2650.

Mohd Nor, N. M., W. Steeneveld, T. van Werven, M. C. M. Mourits, and H. Hogeveen. 2013. First-calving age and first-lactation milk production on Dutch dairy farms. J. Dairy Sci. 96:981-992.

Naylor, J. M., and D. S. Kronfeld. 1977. Refractometry as a measure of immunoglobulin status of newborn dairy calf- comparison with zinc-sulfate turbidity test and single radial immunodiffusion. Am. J. Vet. Res. 38:1331-1334.

Nilforooshan, M. A., and M. A. Edriss. 2004. Effect of age at first calving on some productive and longevity traits in Iranian Holsteins of the Isfahan Province. J. Dairy Sci. 87:2130-2135.

Nocek, J. E., D. G. Braund, and R. G. Warner. 1984. Influence of neonatal colostrum administration, immunoglobulin, and continued feeding of colostrum on calf gain, health, and serum protein. J. Dairy Sci. 67:319-333.

Pirlo, G., F. Miglior, and M. Speroni. 2000. Effect of age at first calving on production traits and on difference between milk yield returns and rearing costs in Italian Holsteins. J. Dairy Sci. 83:603-608.

Robison, J. D., G. H. Stott, and S. K. Denise. 1988. Effects of passive immunity on growth and survival in the diary heifer. J. Dairy Sci. $71: 1283-1287$.

Sejrsen, K., and S. Purup. 1997. Influence of prepubertal feeding level on milk yield potential of dairy heifers: A review. J. Anim. Sci. 75:828-835.

Sejrsen, K., S. Purup, M. Vestergaard, and J. Foldager. 2000. High body weight gain and reduced bovine mammary growth: Physiological basis and implications for milk yield potential. Domest. Anim. Endocrinol. 19:93-104.

Shamay, A., D. Werner, U. Moallem, H. Barash, and I. Bruckental. 2005. Effect of nursing management and skeletal size at weaning on puberty, skeletal growth rate, and milk production during first lactation of dairy heifers. J. Dairy Sci. 88:1460-1469.

Sinha, Y. N., and H. A. Tucker. 1969. Mammary development and pituitary prolactin level of heifers from birth through puberty and during the oestrous cycle. J. Dairy Sci. 52:507-512.

Snijders, T. 2005. Fixed and random effects. Pages 664-665 in Encyclopedia of Statistics in Behavioral Science. Vol. 2. B. Everitt and D. Howell, ed. Wiley, Chichester, UK.

Soberon, F., E. Raffrenato, R. W. Everett, and M. E. Van Amburgh 2010. Early life nutritional management and effects on long term productivity of dairy calves. Energy and protein metabolism and nutrition. Pages 331-332 in Proc. 3rd EAAP International Symposium on Energy and Protein Metabolism and Nutrition, Parma, Italy. Wageningen Academic Publishers, Wageningen, the Netherlands.

Soberon, F., E. Raffrenato, R. W. Everett, and M. E. Van Amburgh. 2012. Preweaning milk replacer intake and effects on long-term productivity of dairy calves. J. Dairy Sci. 95:783-793.

Soberon, F., and M. E. Van Amburgh. 2011. Effects of colostrum intake and pre-weaning nutrient intake on post-weaning feed efficiency and voluntary feed intake. J. Dairy Sci. 94:69-70.

Soberon. F., and M. E. Van Amburgh. 2013. Lactation Biology Symposium: The effect of nutrient intake from milk or milk replacer of preweaned dairy calves on lactation milk yield as adults: A metaanalysis of current data. J. Anim. Sci. 91:706-712.

Soberon, F., and M. E. Van Amburgh. 2017. Effects of preweaning nutrient intake in the developing mammary parenchymal tissue. J. Dairy Sci. 100:4996-5004.

Stanton, A. L., D. F. Kelton, S. J. LeBlanc, J. Wormuth, and K. E. Leslie. 2012. The effect of respiratory disease and a preventative antibiotic treatment on growth, survival, age at first calving, and milk production of dairy heifers. J. Dairy Sci. 95:4950-4960.

Stevenson, M. A., N. B. Williamson, and D. Russell. 2003. Nutrient balance in the diet of spring-calving, pasture-fed dairy cows. N. Z Vet. J. 51:81-88.

Svensson, C., and J. Hultgren. 2008. Associations between housing, management, and morbidity during rearing and subsequent firstlactation milk production of dairy cows in southwest Sweden. J. Dairy Sci. 91:1510-1518.

Svensson, C., K. Lundborg, U. Emanuelson, and S. O. Olsson. 2003 Morbidity in Swedish dairy calves from birth to 90 days of age and individual calf-level risk factors for infectious diseases. Prev. Vet. Med. 58:179-197.

Swanson, E. W., and J. I. Poffenbarger. 1979. Mammary gland development of dairy heifers during their first gestation. J. Dairy Sci. 62:702-714.

Tabachnick, B. G., and L. S. Fidell. 2001. Using Multivariate Statistics. 4th ed. Allyn and Bacon, Boston, MA.

Thompson, J. R., E. J. Pollak, and C. L. Pelissier. 1983. Interrelationships of parturition problems, production of subsequent lactation, reproduction and age at 1st calving. J. Dairy Sci. 66:1119-1127.

Van Amburgh, M. E., D. M. Galton, D. E. Bauman, R. W. Everett, D G. Fox, L. E. Chase, and H. N. Erb. 1998. Effects of three prepubertal body growth rates on performance of Holstein heifers during first lactation. J. Dairy Sci. 81:527-538.

Warnick, L. D. H. N. Erb, and M. E. White. 1995. Lack of association between calf morbidity and subsequent first lactation milk production in 25 New York Holstein herds. J. Dairy Sci. 78:2819-2830.

Zanton, G. I., and A. J. Heinrichs. 2005. Meta-analysis to assess effect of prepubertal average daily gain of Holstein heifers on firstlactation production. J. Dairy Sci. 88:3860-3867. 